\title{
Strategy Support of Residential Energy Saving Investments in Hungary with the Method of Technology Roadmapping
}

\section{Szilvia Bíró-Szigeti}

Department of Management and Corporate Economics, Budapest University of Technology and Economics, Magyar tudósok krt. 2, Building Q, A-309, H-1117 Budapest, Hungary, e-mail: szigetisz@mvt.bme.hu

Abstract: This paper discusses residential energy saving market in Hungary, applying a relatively new method. The study is a comprehensive presentation of the results of an extensive research, exploration of relationship systems and system-based processing, in the framework of which the design, the implementation and the operation of the energy investments of buildings takes place. The market is examined with strategic approach and the reseach findings are systematized in intuitive ways with the method of technology roadmapping (TRM). These aspects of analysis give new and original contribution to the Hungarian building energetics sector and energy policy. The results are obtained from interviews and questionnaire survey with representatives of stakeholder groups and experts. The establishment of residential energy saving investments is highly influenced by environmental factors, technological development of building energy market and stakeholders interests and the interrelation of all these. The problems originate mostly in the long-standing lack of the comprehensive strategic plans and marketing tools of building energetics enterprises and concrete objectives and state's guidelines for the residential market of building energetics.The aim of the study is to serve as a practical instrument for the decision-makers, it can promote more efficient planning, support and implementation of residential energy saving investments.

\section{Introduction}

Residential energy saving approach has become significant in recent decades. As much as $28 \%$ of household energy saving potential [8] can be identified in new or replacement building energy investments in the future. Complex macro- and market level conditions and sustainability requirements effect the realisation of the energy saving investments (both on the demand and supply side) which requires certain marketing features from the enterprises. Building energetics micro and 
small enterprises ${ }^{1}$ have to operate continuously under difficult circumstances due to uncertainty in energy prices, in subsidy systems, in economic condition and social attitude. Competition is increasing, which requires strategic thinking, marketing approach and the use of marketing tools in the corporate functions.

The main objectives of this research are to reveal the building energetics market and the stakeholders of the micro and small enterprises that provide energy saving products and services with a strategic analytical and marketing approach; to systematically organise the available information with the help of TRM methods; and to draw conclusions regarding practical feasibility. These aspects of analysis of the building energetics sector can be considered new and original in Hungary. The necessary information sources were collected and used after the recommendation of the TRM method. The frame of the strategic technology roadmap of the Hungarian residential energy saving is new, the paper can support the development process of this method [43].

In the course of the feasibility studies of Hungarian residential energy saving investments ${ }^{2}$ - when analysing the conditions and the market of energy saving solutions - a knowledge gap occurs between the necessary and available basic information. Studying the traditionally examined factors is vitally important but not enough in itself. There is a lack of indispensable information that should be examined and used but is disregarded by Hungarian research and literature. The state and market level energy policy has not been worked out with processing all the necessary information in a systemic way, using management methods of high standard like TRM so far. In this paper I would like to contribute to the filling of this methodological gap.

At first the TRM method will be presented here (in Chapter 2) briefly, and after that a method will be adapted (in Chapter 3) on the basis of the information available from different sources on the Hungarian residential energy saving investments. Alphabetical symbols and figures help the reader to make the examined background consistent with the related results.

1 Micro-sized enterprise: it is defined as an enterprise which employs fewer than 10 persons and whose annual turnover and/or annual balance sheet total does not exceed EUR 2 million ( HUF 550 million). Small-sized enterprise: it is defined as an enterprise which employs fewer than 50 persons and whose annual turnover and/or annual balance sheet total does not exceed EUR 10 million ( $\sim$ HUF 2,75 billion) [20].

2 The definition of energy saving or building energetics investment is used in this research area in a way that it refers to the new or replacement energy saving investments carried out by micro and small enterprises in the residential and corporate market segment. The term, building energetics includes all building industry products and services (electrical, mechanical, etc.) that actively or passively influence the energy consumption of the building for long-term use. 


\section{The Research Topic and Processing Methods}

\subsection{Brief Description of the Technology Roadmapping Method}

TRM is a widely used method all over the world for developing economic and social policies, making environmental decisions, introducing legislations and laying down $R \& D$ guidelines that contribute to the national level energy policy [37, 40]. Phaal [42] has listed 159 publications that support the application of TRM in the field of energetics. TRM became a popular topic in management literature in the 2000s, the method is still evolving, and has to be further researched and developed.The TRM is used not only at company-level, but industry-level investigations and decision-making too [28]. Industry-level aspect of the method will be discussed in this study, however company-level applications of the method will not be mentioned.

The authors, Phaal, Farrukh, Mitchell and Probert [39] decided that it would be more useful to call the method technology-product, product-, business or strategic mapping. These names express that the method is suitable for the process, product and market prospects of integrating and synchronizing. According to Moehrle, Insenmann and Phaal [31] TRM is ordered directly to strategy and innovation. The roadmap name in this paper contains a strategic approach which is based on research information. Hronszky and Várkonyi [19] distinguish between two main kinds of industry-level roadmapping. In the case of forecasting future trends are more or less predictable, however in the case of foresighting future events are very uncertain. The energy saving strategic technology roadmap, described in this paper, is an example of the first type supporting the forecast.

TRM has no graphing standards like e.g. project management. The standard versions of e.g. network diagrams can be learned from several project management books and other teaching media. These graphic project management tools are more or less standardized, like the symbols of electronic circuit diagrams. However there are several examples for graphing TRM standards but there are no standardized diagramming techniques.

\subsection{The Dimensions of the Roadmap Analysis}

The structural principle of roadmap presented in the study (Figure 1) is suitable for first general-level analysis for the industry, but indirectly, is able to support processes and business level strategies as well. The top layer of TRM is usually called the "market". Experiences show [38] that considering the market in itself is not enough, as sooner or later we always end up analysing the broader environment. The assessment of the company's environment is essential to reveal the strategic situation. The traditional marketing approach divides the environment 
of the company into macro- and micro level [24]. The micro environment covers those elements that have stronger relationship with the company. The model presented in this paper will be constructed by following this principle. In this study Porter's five forces model [44] is used to analyse the micro environment. Furthermore the widely known STEP [1] model is used to analyse the macro environment.

The literature recommends converting maps and graphics structure for the actual specific purposes univocally. The frame of the model is constructed by merging two structural principles [38, 40]. The information is derived on the basis of presented methods and models in section 2.4. Results of the earlier studies are in Chapter 3.

\subsection{Legend}

Time: Three periods are drawn altogether (current, gaps and migration paths, vision).

Categories: micro level enviromental factors (market, suppliers, product and services) and macro level environmental factors (technology, energy policy, economic contraints, social influence and nature).

Subcategories: the environmental factors are divided into subcategories. (The sustainability factors are merged into macro environmental subcategories.)

Key to the symbols of the periods:

- Current phenomena:

- $\quad$ Things to be done (agendas):

- Ideal future trends:

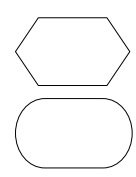

\subsection{Identifying the Knowledge Gaps}

It is important to clarify the knowledge gaps [40] during every step of the TRM process. The necessary information for putting together the strategic technology roadmap of the Hungarian residential-level energetics is partly missing in the literature. I summarize this fragmented information using the insights and recommendations of Duinker and Greig [12], Brummel and MacGillivray [6], Mahmoud et al. [27], Shoemaker [47], Postma and Liebl [45], and Swartz et al. [48] about producing a proper roadmap. Industry-level energy generation is widely covered by the literature but there are only a few cross-references to the residential-level, so the adaptation of the roadmap to the circumstances in Hungary must be limited. That is - among others - why the expected 
technological information and other numbers on the roadmap are taken from a document published by the Japanese Ministry of Economy, Trade \& Industry [21], corrected slightly when it was customized to the situation in Hungary.

The following knowledge gaps are identified as (A) (B) (C) and (D). (A) New energy policy strategic programs, directives, elements of fiscal policy. (B) Need for radical innovations or such new technological trajectories that are not yet visible or are still in the critical experimental phase. (C) Concrete priorities (the roadmap contain the different technological and energy policy areas in general). (D) Future trends and counter-trends, and potential but unexpected events (mainly in the case of the environmental, economic and social factors) that can influence the foresight and cause a shift in any field; the roadmap contains the estimations based on the previously known consumption habits and behaviours.

The majority of the knowledge gaps listed above originate in the lack of the detailed energy strategy in Hungary. The recent map contains changes in attitudes, motivations and resources required from the stakeholders, and it contains their collective and investment risks, furthermore different customer types, that are listed in knowledge gaps of Bíró-Szigeti - Pataki [2] work too.

The background information and specification needed are presented to draw the strategic technology roadmap of residential energy saving investments and interpret the data shown on roadmap (see Figure 1) in the next sections.

\subsection{Information Sources of Macro and Micro Environmental Analysis}

Both primary and secondary information sources were used to the description of the market structure and its dispersion and to the analysis of main participants. Later I will refer to the examined background of the related results in Chapter 3 according to the same classification (alphabetical symbols and figures) below.

(I) Information sources of micro environmental factors and processing methods of the model are detailed below. These were identified as (1), (2) and (3).

(1) The method of in-depth interviews was used to analyse the strategies of the micro and small enterprises (2008-2010). 25 personal (qualitative) interviews were carried out with experts and executives of this subtopic. The obtained information was organised according to (a) Kotler's [25] five factors of competition conditions, (b) Doyle [11] differential advantages model (c) Doyle [11] customer needs, $(d)$ consumer decision-making processes [13, 34], (e) decision-making unit and consumer behaviour models [50], as well as $(f)$ other corporate and marketing strategy describing standard methods and tools.

(2) Detailed analyses were carried out concerning building energetics micro and small enterprises and the energy saving investments, based on the online 
(quantitative) questionnaires. The objective of the research was to reveal the market position, strategies, management knowledge, customer value and success factors of the building energetics micro and small enterprises, and also to compare the results in different segments. The online data survey took place in 2010. The enterprises in HBI 2010/1 company database were considered as population, that was classified on energy, energy building technology, building and electrical Hungarian NACE (TEÁOR) numbers (4110, 4120, 7111, 7112 and 7120). There were 2549 companies altogether. Each of them was asked to complete the questionnaire. Thus this survey can be considered complete. 212 questionnaires were analysed altogether. The response rate was around $8.3 \%$ for the main population and also for the total sample. The respondents are representative for the range of energy saving investment projects of the enterprises. The representation was examined on the basis of company size property: sales and number of employees. The results from the survey include information of the subcategories of the Figure, 'Market' and 'Goods and services'.

(3) Both secondary (literature) and primary (in-depth interviews) sources were used to reveal the stakeholders' interests and relationships, and the gained information was organized, according to the "stakeholders of environmental investments" method [3] developed by Overseas Development Administration (ODA) [35]. The results and the conclusions of the ODA analysis can help to increase the number and the rate of the successful residential energy saving investments [4]. On this subtopic, 17 in-depth (qualitative) interviews were conducted with experts and executives according to stakeholders' analysis method. The main results of the analysis of the models 'Suppliers' were built in category 'Public energy company', 'Financial institution', 'University, Research institute' subcategories of the Figure. The 'Energy Policy' category of the Figure contains information on state, local governments, environmental and other influencers.

(II) Macro environmental factors of the theme are based on the literature of secondary sources, which is detailed in section 3.2. These are the well known macro environmental factors of the STEP model that was extended in several ways. The roadmap is made up of layers which represent the usual structure of STEP model of the following environmental factors: 'social influence', 'technological', 'economic constraints', '(energy) political', and - in this context - 'natural (ecological)'. In particular, the technologies were previously analysed in the form of a so-called "Technology roadmap on the Hungarian residential energy saving" [2], showing each technological development tendencies. It is important to note that energy policy can be connected to mostly every other layers because residential-level building energetics is a tightly state controlled industry. The particular entities on the roadmap could be assigned for more than one environmental factor, so this layout is only one of the possible graphing structures. 


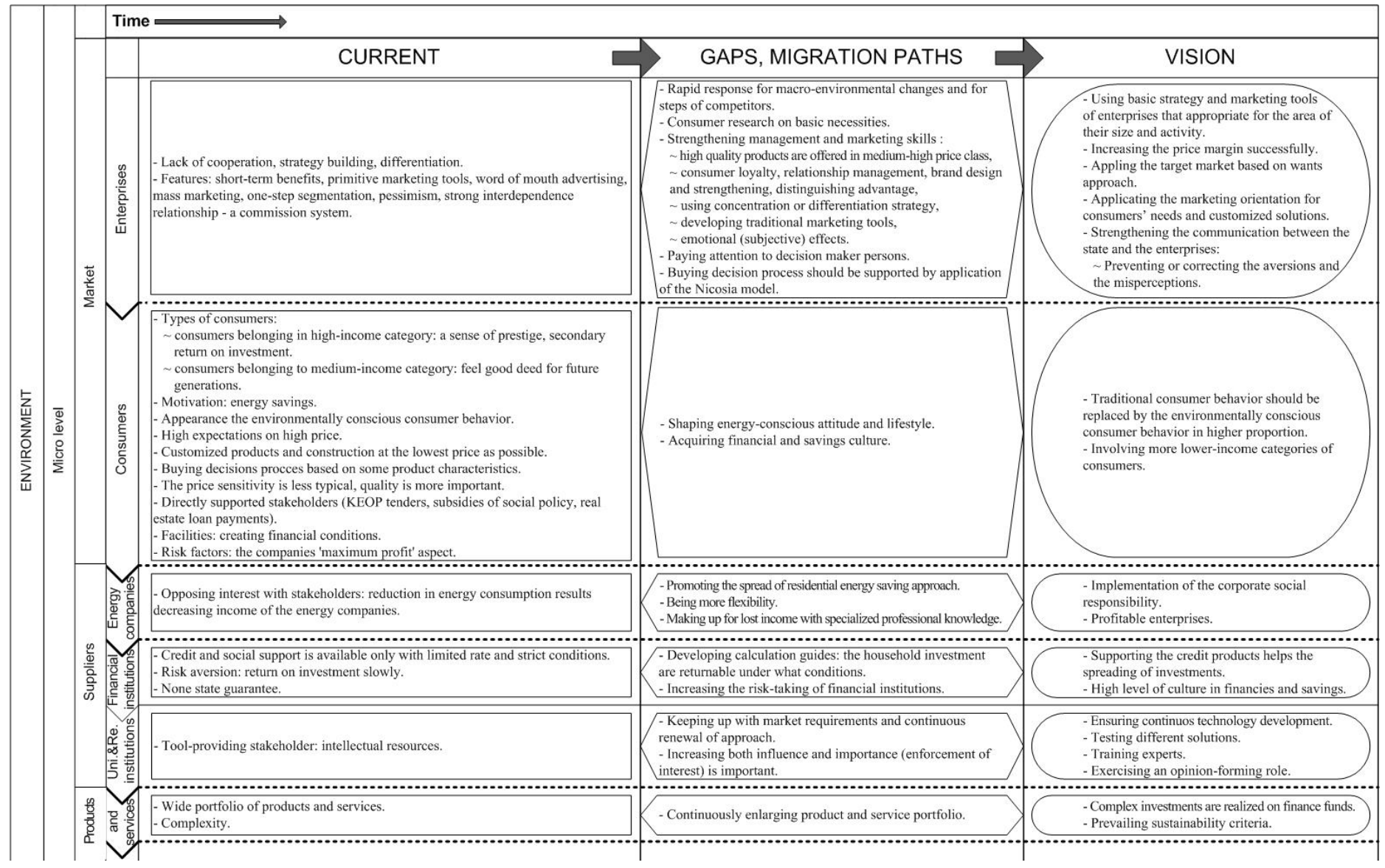




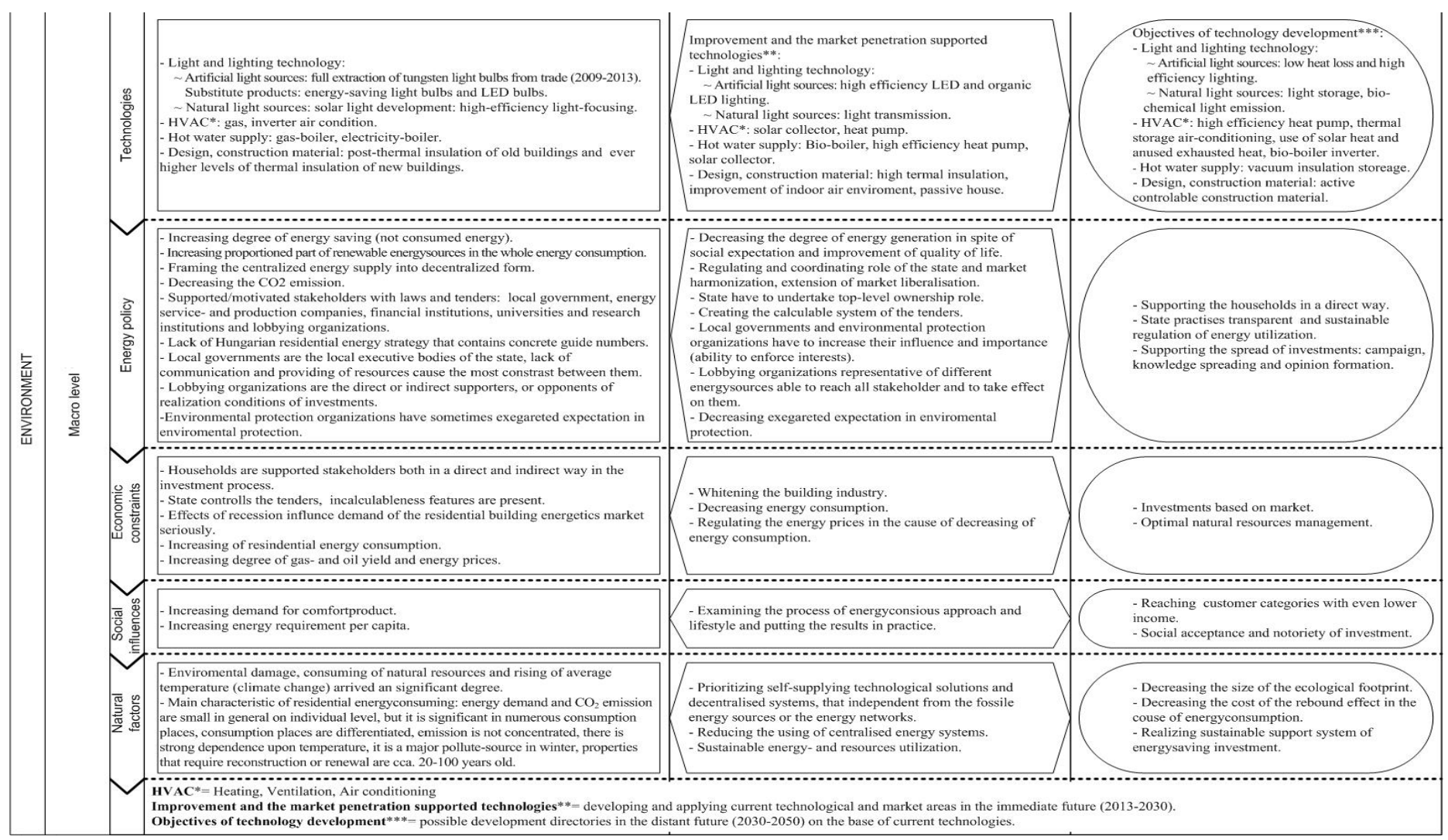

Figure 1: Strategic technology roadmap of the Hungarian residential energy saving.

Source: own figure. Using data from: $[4,2,5,7,9,10,14,15,16,17,18,21,26,29,30,33,36,38,41,44,49,51]$ 


\section{Presentation of Results and Discussion}

\subsection{Results from the Micro Environmental Analysis (I)}

(1) One of the main directions of this research is to identify the strategy of building energetics enterprises, its product- and service concepts and, the main characteristics and requirements of the customers in an indirect way. In the following those research results are detailed that were obtained on the basis of the models already described in paragraph (1) of the section 2.2. These were identified as $(a),(b),(c),(d),(e)$ and $(f)$.

(a) There is no cooperation among the competitors on the residential market. Aggressive position-taking can be seen region-wide to deter the competitors when a new technology or a product is launched. The enterprises are continuously making price comparisons and also they have different missions and objectives for their operation fields. Their main business objective is the same (to win orders and to generate profit).

(b) Enterprises do not have conscious corporate strategy, however, they can adapt successfully to the changing environment. They mainly use basic marketing tools. The word-of-mouth advertisement has a significant role when they are doing business. They do not know or realize the added-value of their products or services. There is a tendency in the building energetics sector that the profit of the businesses will be attributed to the selling of the physical products at a decreasing rate. Currently, most of the micro and small enterprises are willing to do business with anyone who can pay for their products and services. In this way, the enterprises will have a large number of customers with low profit margin. Furthermore, they lay more emphasis on the short-term benefits than long-term profits. The factors of the customer value analysis for determining the value offer can be divided into two groups. The sense of prestige dominates among the highincome customers, and the return on investment is a secondary criterion, whereas among the middle-income customers, the sense of a positive step for the sake of the future generations dominates. However, high expectations that are attached to high prices can create substantial customer value in both categories. Even if the enterprises are able to name some of their target groups, they usually do not use different communication strategies for addressing them or also to attract them with different marketing tools. They communicate and behave differently with consumers depending on the personality of the salesman and/or the contractor based mainly on their knowledge of human nature. Their strategic tools are quite similar to mass marketing. 
(c) The enterprises do not analyse the customer needs due to time and resource limitations. Moreover, it is difficult for them to formulate a need that they could not possibly satisfy, because it would cause a competitive disadvantage for the enterprises.

(d) The classical model of consumer buying decision process [13] was changed to a 0+5-step model, that is very similar to the Nicosia-model [34]: 0. Interest, 1. Problem awareness 2. Information search 3. Evaluation of alternatives 4. Purchase 5. Post-purchase evaluation.

(e) Most of the time, the decision maker is a person with technological and economic background, but other family members, and sometimes even friends, acquaintances and colleagues can influence the decision making process. It can be assumed that the buying decision is based on some product characteristics. The traditional consumer behaviour has to be replaced by the environmentally conscious consumer behaviour to a greater extent in order to increase the number of successful investments.

(f) The results presented that only a small part of the analysed building energetics enterprises use conscious segmentation in the sphere of the residential market. Most of the time, the segmentation is built on a certain technology and rarely on the information obtained from the analysis of the consumer behaviour, or the values that the customers expect. Segmentation is usually done in one step, i.e. the enterprises categorise the customers on the based of only one criterion.

(2) Results of quantitative market research in paragraph (2) of section 2.2 will be presented in the following. The following factors were analysed in the empirical research in order to reveal the market success and marketing management characteristics of the micro and small enterprises undertaking building energetics investments: identifying and evaluating the marketing operation (tools and strategies); the quality and price of the product and the income situation of the customers; the number and characteristics of the products and business operations; mission; consumer loyalty; subjective and objective factor of success; price sensitivity; and the importance of energy saving. The more an enterprise undertakes higher-level and extended marketing operations, the more successful it can become. Based on the variables of the analysis included, it can be stated that this increases the importance of the differential strategy. Positioning for product quality plays a crucial role in increasing success among the marketing operations. A connection was discovered between the product quality and the price level. The most successful strategy is to offer high quality products for high or medium price. Successful building energetics enterprises are optimistic about their future prospects. They consider the market to be continuously expanding and their increasing margin reflects a rising demand. Their customers are loyal, which indicates adequate sales and communication activities and assumes branding. The subjective factors (they are not easily measurable and quantifiable, or they build on emotions) proved to be the most successful marketing tools among the factors 
of success. Indirectly, this can relate to the conscious and wide-ranging marketing activities of the enterprises. The recession has exerted a more dramatic impact on the demand of the residential market. Due to this fact the enterprises see their future more pessimistically on the residential market. Based on the opinion of the survey respondents, the energy saving motivation is more dominant in this market segment that can be considered as an important factor when developing a strategy that builds on the costumers' (stakeholders) motivation. In the residential market, marketing tools play a more significant role in sales and can be used much more efficiently. Moreover, enterprises have developed different communication and sales strategies for their target groups. The primary stakeholder groups identified in the residential customer segment are less price sensitive than the corporate segment. This partly contradicts the "standard" marketing concept that consumers are price sensitive, whereas corporations - mainly business corporations - are not, or less, since they add their costs to their products and make their customers pay for them. Moreover, it can be stated on the base of the research results that the supply of the enterprises operating on the residential market includes wider range of products and services and these are more complex.

(3) Third main direction of our primary market research is the stakeholder analysis. The results will be described in the following. The methodology was already presented in paragraph (3) of section 2.2 formerly. The lack of interest appears in case of two primary stakeholders (building energetics enterprises and household customers) in connection with the financial terms and targets. "Maximum profit" approach of enterprises could mean risk factor for the customers, if the quality of professional implementation and the return of residential investment are compromised. The customer base is narrowed down primarily according to their income due to the typically high investment cost. The four groups of the enterprises can be identified in scope of activities: manufacturers, designers, distributors and constructors. These enterprises ensure the necessary tools for mental and physical implementation. There are strong interdependence relationships between these enterprises. Their investment interests are mostly derived from the recommendations / mediation fees received directly from manufacturers and these are proportional with commission rate. The primary stakeholders have financial (savings, loans, grants, equity), mental (expertise, innovation), total assets (technology, labour, real estate) resources. The problems usually occur in financial resources and pose a barrier to the realization of investments. Among the primary stakeholders, the household customers are supported in the process both directly and indirectly. However, I met a number of references in the qualitative research that indirect forms of support (mainly aimed at whitening the building industry) have not been successful. Any organizations that can serve valuable / useful information for the creation of the investments were considered suppliers - in addition to the traditional interpretation. In this context, the following statements for suppliers were made: energy service- and production companies should equip themselves with great flexibility and advanced technical knowledge in the future that is characteristic of small 
enterprises, which attracts the modification of the legal background as well. The taking risk of financial institutions should be increased for spreading of loan products. Increasing both influence and importance would be important for universities and research institutions because they can fall out the scope of secondary stakeholders due to the improper lobbying.

\subsection{Results from the Macro Environmental Analysis (II)}

The macro environmental band of the model describes the current trends and what changes are necessary that influence the market and the implementation conditions of the investments. Resources of the discussed secondary stakeholders (state, local governments, environmental organizations and lobbying) are extremely complex, vary according to each stakeholder subcategory of the Figure. Consumption of resources has significant impact on household energy savings investment plans and their feasibility. The economic, the social and the environmental factors are the same with the basic pillars of sustainable development. Ideally, states should take all these three elements into account to shape their energy policy that, as the model also shows, has impact on the developing technology areas. Macro environmental and sustainability aspects of this study have already been consulted by Bíró-Szigeti [4]. The gathered information is summarized in the form of the rough strategic technology roadmap.

The main technological possibilities appearing in residential energy saving areas are following $[21,29,51]$ : to develop new lighting technologies: conservation and using natural light, different models of LED, with low heat loss and high efficiency luminous bodies; to develop HVAC (heating, ventilating, air conditioning) and hot water supply: to replace air-conditioning equipment, to equip heat pump and solar collector, to use unused energy/heat; to develop energy saving planning and construction materials for housing and building: developing materials for thermal insulation and applying to building materials. Further possibilites are: spreading high quality housing by convenient and highly accurate housing performance design and assessment technologies.

Energy policy. The biggest knowledge gap is in the field of the Hungarian household energy saving strategy. Hungary currently has no comprehensive, detailed and coherent energy strategy that contains concrete (with data plans and feasibility) goals. The available guidelines and concepts are not sufficient. Control of the state coordinating role and market harmonization are essential for the next steps [33]. State has to undertake top-level ownership role over the industry roadmap, because serious results can not be expected without lack of top-level ownership. The state has a major role and attempts to provide support policies (laws and regulations) and incentives (tenders) for the local authorities, energy suppliers and energy companies, financial institutions, universities and lobby organizations as top-down pressure. Organizations representing the fossil fuel 
lobby are able to influence almost all the stakeholders. It would be necessary to reduce the excessive environment protection requirements of the environmental protection organizations. It would be important to improve the influence and the significance of the environmental organizations and the local authorities, because they could fall out of the scope of secondary stakeholders due to inadequate lobbying.

Social influence. Energy demand decreases if for example the population decreases [45], or the energy conscious way of thinking and lifestyle is spreading (i.e. the demand for air conditioning is reduced), and if new buildings are designed in a more enviromental friendly way as a result of complex energy saving housing (houses with low energy demand, passive houses) [21, 29]. By the spreading of environment-conscious thinking and technology applications broader and broader consumer range and consumer categories with lower and lower income levels can be reached and involved into saving energy. Fábián et al. [16] separated the main groups of Hungarian society in the course of their research according to three ranking criteria: flat, material and cultural consumption. The first group is the elite characterized by outstanding material and cultural consumption, the second is the wealthy group, the third is the group that accumulate savings, the fourth is the free time oriented group, the fifth is the deprived group with good flat, and the sixth is the deprived-poor. Building energetics investments can be accomplished in the first place by the members of the first three groups (elite, wealthy and the group that accumulate savings) because of their motivation, values and financial situation. The conclusion of their research is that the exploration of the possibilities of crossing the boarders of the separate consumption models could contribute to the motivation of some particular consumption patterns and to the understanding of the tools of influencing the formation of consumption patterns.

Economic constraints. The most important technological requirement in the residential building energetics sector is that the energy consumption per household must be reduced by $80 \%$ till 2100 , in spite of the fact that in the same time the share of energy consumption within the GDP is expected to increase continually [7]. Increasing proportion of energy consumption within the GDP appears to be unavoidable because every government tries to raise the living standard but it involves more demand for energy [7, 15]. The share of electric energy within all types of energy should reach $100 \%$ by 2100 [21]. Within electric energy the proportion of fossil energy sources should be continually decreased. This requirement involves that the energy demand of buildings and household appliances, the usage of long distance transmission line networks, the magnitude of centralized energy generation, and $\mathrm{CO} 2$ emission must be reduced. The proportion of renewable energy sources and operations by using electricity must be increased while the users' comfort level and other requirements must be maintained $[10,15]$. It can be stated that the spread of investments cannot be expected to be based on only the market, so cooperation of the secondary stakeholders, strengthening and harmonization of their interest with the 
investment might get to the foreground. The responsibilities and influences of the secondary stakeholders impact the establishing of the residential energy saving investment to greater extent.

Natural factors. The residential sector is typically characterized by physical factors $[9,21]$. These should be considered when the substitution or the energy saving replacement of the currently most widely used technologies with alternative technological solutions in the future is planed. Climate change and population growth determine the size of the ecological footprint. The running out of our energy resources, the decreasing natural ground area, and the increasing population are continuously reducing the size of the ecological footprint per capita while the inhabitants of the developed and developing countries have bigger and bigger ecological footprints [36]. The less is the magnitude of the rebound effect [22] and the more efficient is the operation of the new energy saving devices, the higher living standard can be achieved with the same ecological footprint size [18]. At last but not least one of the most serious natural factors urging energy saving is the rise of the average temperature, resulting in climate change. Signs of climate change appear in temperature and precipitation intensity and frequency contexts in Hungary [33]. Expert opinions diverge about of the magnitude of this future change, but this problem must be taken seriously and must be dealt with.

\section{Conclusions}

The study aims to contribute to description of the current state of the Hungarian building energetics market and the residential energy-saving investments with a specific approach. The approach provides system and market (strategic) aspects for the variety stakeholders in the energy saving market. Complex framework conditions of the residential building energetics investments will be summarized on the base of the literature and the expedient collected primary information. I assumed if I developed a strategic technology roadmap than the necessary information would be currently available, on the base of which the proposed model can help to define the main guidelines of consistent energy policy and strategy for the long-term and successful marketing strategy and tools for building energetics enterprises.

I collated and summarized the most important information from the result of the enviromental analyses (in section 3.1 and 3.2) and from the strategic technology roadmap. Note that these results contain complex information from macro and micro level analyses which are necessary together for the most important actions to achieve the 'Vision' future state proposals (see Figure 1). These results (in conclusion form) were identified as (i), (ii), (iii) and (iv). The issues could been parallel between some results from other SME's researchwork [23].

(i) To fulfil the required technological, economical, social and natural expectations in the residential sector the energy consumption must be reduced in the first place. At this point those household appliences and pieces of equipment should be taken into consideration that will come out only in the future. In the 
second place such energy generation methods must be found that utilize continuously available renewable resources like solar and geothermal energy. Those technological solutions and decentralised systems are prioritized which are self-supplying, independent from the fossil energy sources or the energy networks. In this way less energy produced by the existing (centralised) energy system will be transmitted for long distances, consequently efficiency can be increased and energy generation demand can decrease.

(ii) State and industrial coordination of implementation of the residential energy saving investments - in relation with sustainability criteria - is burdened with numerous problems. There is a lack of strategic plan and state guidelines that contain concrete goals and comprehensive to the building energetics industries. The available guidelines and concepts are not adequate. The regulating and coordinating role of the state, as well as the market liberalisation are essential for the next steps. The work of a multidisciplinary expert team would be necessary to develop a complete energy strategy plan for Hungarian that is acceptable for all stakeholders.

(iii) It is difficult for consumers to take energy-saving efforts themselves due to existing misconceptions, lack of information, and any bad experiences, lack of financial resources and short-term thinking, etc., while the energy prices are continuously rising, the demands of the comfort level are getting even higher and the residential energy saving has increasing impact on the national economy. It would be necessary to spread energy-conscious attitudes and lifestyle for the environmentally conscious consumer behaviour. Higher level financial and savings culture could support the market size and the number of segments efficiently in the future.

(iv) Micro and small enterprises in the building energetics sector present strategic behaviour, the modern marketing concept and many elements of marketing tools in their practice, but at low levels, due to the skill gaps, resulting mostly nonconscious and non-systematic marketing management application. The success factors of marketing strategies and tools of the building energetics micro and small enterprises are summarized in the following. These could serve as examples to establish future strategies. These are based on the differential advantage concept, follow a focus strategy, and offer high quality products in the medium or high price category. Consumer loyalty and relationships, brand name and subjective (not easily measurable and quantifiable) factors dominate among the marketing tools of the successful building energetics enterprises. Moreover, their product portfolio and field of operations will be characterised by increasing market demand and margin.

The strategic technology roadmap is not complete in its present form. In order to improve it the most important elements of the knowledge gap were collected. Further studies and research in the following areas are needed especially to fill the knowledge gaps. That work can be continued exclusively by a multidisciplinary 
expert team: to examine customer specifications; to survey social misconceptions; to adapt success enterprise strategies in different business segments; to research applicable technologies and future development trends; to complete the Hungarian state energy strategy. The roadmap is applicable to develop the corporate-level roadmap for building energetics enterprises. So the enterprises can customize it into the field of their activity and market in their strategy.

In addition, the results of the study can serve with practical information for the concerned enterprises, and may also be used for the state or other institutional stakeholders to design the promoting energy savings policy decisions (regulations, subsidies) in residential building energetics and to evaluate their effectiveness. If the energy efficient building energetics investments spread on market based, it would have a positive impact on the economic, social and natural environment of Hungary, and so it could support sustainable development in long-term.

\section{Acknowledgement}

Thank for methodologycal advices and helping my work for Mária Vágási, PhD, associate professor; Béla Pataki, $\mathrm{PhD}$, associate professor and Györgyi Danó, $\mathrm{PhD}$ student, market researcher.

\section{References}

[1] Aguilar, F. J.: Scanning the Business Environment, Macmillan, New York, 1967

[2] Bíró-Szigeti Sz., Pataki B.: Applying Technology Roadmapping for the Energy Saving Industry, Periodica Polytechnica - Social and Management Sciences 20:2, 2012, pp. 105-113

[3] Bíró-Szigeti Sz., Vágási M.: A háztartási energiamegtakarítási beruházások érintettjeinek rendszerelvű megközelítése - egy kutatás tapasztalatai alapján (Systemic approach of the residental energy saving investments stakeholders - Based on the experience of a research) (in Hungarian), in: Topár J. (ed.): A müszaki menedzsment aktuális kérdései, Müszaki Kiadó, Budapest, 2012, pp. 323-342

[4] Bíró-Szigeti Sz.: Mikro- és kisvállalkozások marketingfeltételeinek vizsgálata az energiamegtakarítás lakossági piacán (Analysing the marketing conditions of the micro and small enterprises on the residential energy saving market) (in Hungarian), PhD dissertation, Budapest University of Technology and Economics, Budapest, 2011

[5] BPA (Bonneville Power Administration): Energy Efficiency Technology Road Map, USA BPA Technology Innovation Office, 2006 http://ieeexplore.ieee.org/xpl/login.jsp?tp=\&arnumber=4077537\&url=http $\% 3 \mathrm{~A} \% 2 \mathrm{~F} \% 2 \mathrm{Fieeexplore.ieee.org \% 2Fxpls \% 2Fabs \_ all.jsp \% 3Farnumber \% 3}$ D4077537

[6] Brummel, A., MacGillivray, G.: Introduction to Scenarios 
http://scenarios2strategy.com/pdf/Introduction $\% 20$ to $\% 20$ Scenarios $\% 20$ and $\% 20$ Scenario $\% 20$ Planning.pdf

[7] CEC (Commission of the European Communities): A Technology Roadmap for the Communication on Investing in the Development of Low Carbon Technoilogies (SET-Plan). Commission staff working document. SEC(2009) 1295, Brussels, 2009

http://eurlex.europa.eu/LexUriServ/LexUriServ.do?uri=COM:2009:0519:F IN:EN:PDF

[8] CEC (Communication from the Commission): Action Plan for Energy Efficiency: Realising the Potential. COM(2006)545 final SEC(2006)11731175, Brussels, 2006 http://eurlex.europa.eu/LexUriServ/LexUriServ.do?uri=CELEX:52006DC 0545:HU:NOT

[9] Csete J., Horánszky B., Szunyog I.: A lakossági energiafelhasználás környezetterhelése (Enviromental load of residential energy consumption) (in Hungarian), Energiagazdálkodás, 46:5, 2005, pp. 19-25

[10] Dinya L., Domán Sz., Fodor M., Tamus A.: Ökoenergetikai marketing kihívások (Eco-energetics marketing challenges) (in Hungarian), Marketing Oktatók Klubjának 12. Országos Konferenciája, Conference proceedings on $\mathrm{CD}$, Budapesti Müszaki és Gazdaságtudományi Egyetem, Budapest, 2006

[11] Doyle, P.: Value-based Marketing: Marketing Strategies for Corporate Growth and Shareholder Value. Wiley, Pennsylvania, 2000

[12] Duinker, P. N., Greig, L. A.: Scenario Analysis in Environmental Impact Assessment: Improving Explorations of the Future, Environmental Impact Assessment Review, 27:3, 2007, pp. 206-219., cited in: Moen, 2009

[13] Engel, J., Blackwell, R., Kollat, D.: Consumer Behavior, Rinehart and Wiston, New York, 1973

[14] EPT (Európai Parlament és Tanács): 2010/31/EU irányelve az épületek energiahatékonyságáról - átdolgozás (2010/31 EU policy on the energy efficiency of buildings - revised version) (in Hungarian), 2010 http://eurlex.europa.eu/LexUriServ/LexUriServ.do?uri=OJ:L:2010:153:001 3:0035:HU:PDF

[15] EREC (European Renewable Energy Council): Renewable Energy Roadmap up to 2020, Renewable Energy House, 2007 http://www.erec.org/fileadmin/erec_docs/Documents/Publications/ERECTechnoloy_Roadmap_def1.pdf

[16] Fábián Z., Kolosi T., Róbert P.: Fogyasztás és életstílus (Consumption and lifestyle) (in Hungarian), in: Kolosi T, Tóth I, Vukovich Gy, (ed.): Társadalmi riport 2000 (Social report 2000), TÁRKI, Budapest, 2000, pp. 346-376 
[17] GKM (Gazdasági és Közlekedési Minisztérium): Magyarország megújuló energiaforrás felhasználás növelésének stratégiája 2007-2020 (Hungary's strategy for increasing the usage of renewable energy sources 2007-2020) (in Hungarian), GKM, Budapest, 2007

[18] Harangozó G.: A javuló energiahatékonyság szerepe az energiafelhasználás csökkentésében: lehetőségek és buktatók (The role of improving energy efficiency in the reduction of energy consumption: opportunities and obstacles) (in Hungarian), Budapest, BCE, 2009

http://www.uni-corvinus.hu/index.php?id=26651

[19] Hronszky I., Várkonyi L.: Radikális innovációk menedzselése (Managing radical innovations) (in Hungarian), Harvard Businessmanager, 8:10, 2006, pp. $28-41$

[20] HUP (Hungarian Parliament): 2004. évi XXXIV. törvény a kis- és középvállalkozásokról, fejlödésük támogatásáról (Act XXXIV of 2004: Small and Medium-sized Enterprises and their Development Act) (in Hungarian), 2004

http://net.jogtar.hu/jr/gen/hjegy_doc.cgi?docid=A0400034.TV

[21] IAE (Institute of Applied Energy: Japanese Ministry of Economy, Trade \& Industry): Strategic Technology Roadmap (energy sector) - energy technology vision 2100, 2005

http://www.iae.or.jp/2100/main.pdf

[22] Jevons, W. S.: The Coal Question. An Inquiry Concerning the Process of the Nation, and the Probable Exhaustion of our Coal-Mines, MacMillan, London, 1865

[23] Kadocsa, Gy., Francsovics A.: Macro and Micro Economic Factors of Small, Enterprise Competitiveness. Acta Polytechnica Hungarica, 8:2, 2011, pp. 23-40

[24] Kotler, P.: Marketing Management, $11^{\text {th }}$ ed., Prentice Hall, Englewood Cliffs, 2003

[25] Kotler, P.: Marketing menedzsment, Budapest, KJK-KERSZÖV, 2004

[26] KvVM (Környezetvédelmi és Vízügyi Minisztérium): Nemzeti Éghajlatváltozási Stratégia (National climate change strategy) (in Hungarian), PRUDENCE project, 2007

klima.kvvm.hu/documents/14/NES_6.4c.pdf

[27] Mahmoud, M., Liu, Y., Hartmann, H., Stewart, S., Wagener, T., Semmens, D., Stewart, R., Gupta, H., Dominguez, D., Dominguez, F., Hulse, D., Letcher, R., Rashleigh, B., Smith, C., Street, R., Ticehurst, J., Twery, M., van Delden, H., Waldick, R., White, D., Winter, L.: A Formal Framework for Scenario Development in Support of Environmental Decision-Making, Environmental Modelling \& Software, 24:7, 2009, pp. 798-808, cited in: Moen, 2009 
[28] McCarthy, R. C.: Linking Technological Change to Business Needs, IEEE Engineering Management Review, 31:3, 2003, pp. 49-53

[29] Medgyasszay P.: Fütési energia megtakarítás épület léptékben (Saving heating energy on the scale of buildings) (in Hungarian), 2007a http://fenntarthato.hu/epites/leirasok/nes/futes-epulet-leptekben

[30] Medgyasszay P.: Várható éghajlatváltozás hatása az épített környezetre (The effect of the expectable climate change to the built environment) (in Hungarian), 2007b http://fenntarthato.hu/epites/leirasok/nes/eghajlatvaltozas-hatasa

[31] Moehrle, M. G., Isenmann, R., Phaal R.: Technology Roadmapping for Strategy and Innovation, Springer, New York, 2013

[32] Moen, J., Jonsson, R.: Scenarios in the context of Future Forests, Future Forests Working Report, 2009, p. 11

http://www.futureforests.se/download/18.5686ae2012c08a47fb5800023704 /Scenarios+in+the+context+of+Future+Forests.+PDF.pdf

[33] NeFMi (Nemzeti Fejlesztési Minisztérium): Nemzeti Energiastratégia 2030 (National Energy Strategy 2030) (in Hungarian), 2011 http://www.kormany.hu/download/5/39/40000/Energiastrategia.pdf

[34] Nicosia, F.: Consumer Decision Process, Prenntice Hall, Englewood Cliffs, New York, 1966

[35] ODA (Overseas Development Administration Social Development Department): Guidance note on how to do stakeholder analysis for aid projekts and programmes, London, 1995

[36] Pappné Vancsó J.: Az ökológiai lábnyom számítási módszerének bemutatása Magyarország példáján keresztül (Introducing the calculation method of ecological footprint through the example of Hungary) (in Hungarian), Táj, tér, tervezés, Geográfus Doktoranduszok VIII. Országos Konferenciája, Szeged, 2004 http://geography.hu/mfk2004/mfk2004/phd_cikkek/pappne_vancso_judit.p df

[37] Pataki B., Bányai A.: Egy új stratégiai eszköz: a technológiai úttérképezés. (A new strategic tool: technology roadmapping) (in Hungarian), CEO 11:1 2010, pp. 8-12

[38] Pataki B., Bíró-Szigeti Sz., Szalkai Zs.: Company-level Technology Roadmapping, in: Ran, B. (ed.): The Dark Side of Technological Innovation (Contemporary Perspectives on Technological Innovation, Management, and Policy) Information Age Publishing, Charlotte, 2013, pp. 83-109

[39] Phaal, R, Farrukh, C, Mitchell, R, Probert, D, Starting-up Roadmapping Fast, IEEE Engineering Management Review, 31:3, 2003, pp. 54-60 
[40] Phaal, R., Farrukh, C., Probert, D.: Customizing Roadmapping, ResearchTechnology Management, 47:2, 2004, pp. 26-37

[41] Phaal, R., Farrukh, C., Probert, D.: Technology Roadmapping - A Planning Framework for Evolution and Revolution. Technological Forecasting and Social Change, 71, 2003, pp. 5-26

[42] Phaal, R.: Public-Domain Roadmaps, Centre for Technology Management University of Cambridge, 2009

http://www.ifm.eng.cam.ac.uk/uploads/Research/CTM/Roadmapping/publi c_domain_roadmaps.pdf

[43] Phaal, R.: Roadmapping Bibliography, University of Cambridge, 2013 http://www.ifm.eng.cam.ac.uk/uploads/Research/CTM/Roadmapping/Road mapping_Bibliography_Phaal.pdf

[44] Porter, M. E.: How Competitive Forces Shape Strategy. Harvard Business Review 57:2, 1979, pp. 86-93

[45] Postma, T. J. B. M., Liebl, F.: How to Improve Scenario Analysis as a Strategic Management Tool?, Technological Forecasting and Social Change, 72:2, 2005, pp. 161-173

[46] PRB (Population Reference Bureau): 2010 World Population Data Sheet, Washington, 2010 http://www.prb.org/pdf10/10wpds_eng.pdf

[47] Shoemaker, P. J. H.: Twenty Common Pitfalls in Scenario Planning, in: Fahey, L., Randall, R.M. (eds.): Learning from the Future, Competitive Foresight Scenarios, Wiley, New York, 1998, pp. 422-431, cited in: Moen, 2009

[48] Swartz, P.,: The Art of the Long View, Doubleday, New York, 1991, cited in: Moen, 2009

[49] TNM (a regionális fejlesztésért és felzárkóztatásért felelős tárca nélküli miniszter): 7/2006. (V.24.) TNM rendelet az épületek energetikai jellemzőinek meghatározásáról (minister without portfolio regulation of determining the energetics characteristics of buildings) (in Hungarian), 2006 http://net.jogtar.hu/jr/gen/hjegy_doc.cgi?docid=A0600007.TNM

[50] Törőcsik, M.: Fogyasztói magatartás trendek - új fogyasztói csoportok. (Consumer Behaviour Trends - New Customer Groups) (in Hungarian) KJK-KERSZÖV, Budapest, 2003

[51] Ürge-Vorsatz D., Füle M.: Economics of Greenhaus Gas Mitigation, Hungary Country Study, Prepared for UNEP, 1998 